\title{
(UN)CERTAIN GHOSTS
}

\section{Rephotography and historical images}

\author{
Mary Agnes Krell
}

This chapter is borne of days walking the streets of St Malo, stacks of photographs in our arms as we looked for traces of the past in buildings and streets. It attempts to articulate multiple sites of encounter in the viewing and, crucially, making of a rephotographic image. While there has been some scholarly exploration of the nature of rephotographic images and the promise they offer viewers, far less has been written about the photographic acts involved and the new knowledges that might emerge from those. The ghosts in the title refer simultaneously to the original photographers and to the people and places who have disappeared from the spaces and places we inhabit.

\section{On Lee Miller}

Lee Miller was the first female photographer to enter Normandy with troops during the Second World War. She was working in a freelance capacity for Vogue magazine in England during that time. She was also one of a small number of female photographers officially accredited by the Allies. Miller was an American expat and was therefore able to obtain permission to work as an actual war correspondent, making her the first woman to write and photograph her own stories from that time. In her capacity as a reporter for Vogue she produced a series of reports on her experiences. For each, she provided the magazine with photographs and her own written accounts of activities. Not long after returning from the war, those images, notes and ephemera were boxed and placed in an attic only to be rediscovered decades later by her son.

This chapter emerges from a project exploring those materials and focusing on Miller's own words, images and marginalia. She was a photographer and author whose life was often framed through her proximity to famous men with whom she lived, worked and loved. She is sometimes included in discussions of surrealist art both because her early work shows surrealist influences and because she worked 


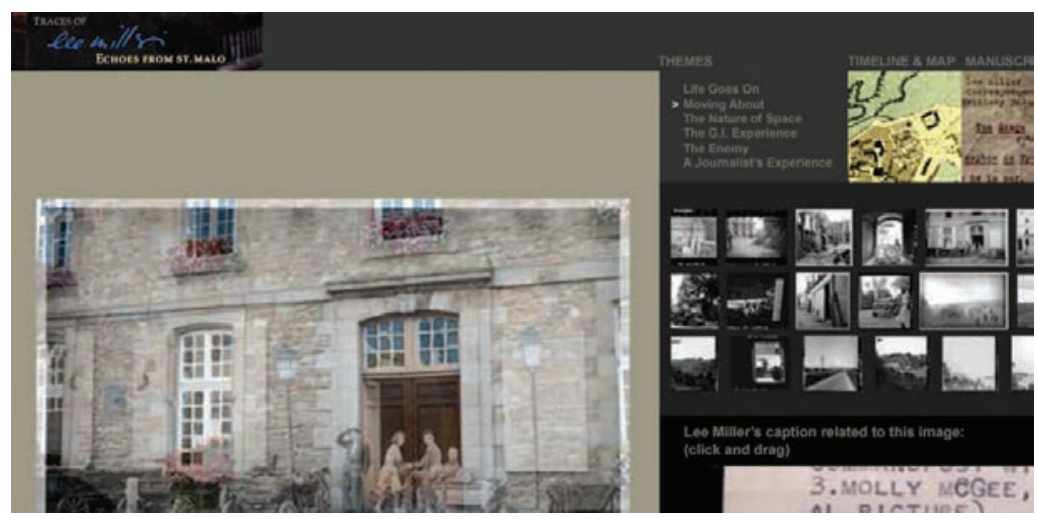

FIGURE 5.1 Screenshot from the project, 'Traces of Lee Miller: Echoes from St. Malo'.

and associated with many famous individuals from the period. Such a narrow reading of her life and work is problematic. For that reason, the project at the core of this article consciously focused on her own work, and not her work with Man Ray or her collaborations with her husband Roland Penrose and others.

Miller's war photography presents a unique and personal account of war. It warrants further study and, as such, we chose to focus on her time in St Malo in Normandy, the place at which she first saw battle, to begin our work. Miller was sent to St Malo but, as a result of misinformation, arrived not after but in the midst of the city's siege. Women were not supposed to see combat but Miller landed at the heart of it. During the following week or so her life and her photographic practice would change significantly. This period in Miller's life, and - I would argue - this very moment in St Malo changed her work from the somewhat surrealist (almost playful) early images to darker and more complex material.

In light of those experiences and that notional moment of transition, we produced a project with rephotography at its core. Alongside the rephotographs is a wide range of materials including Miller's contact sheets, captions, personal notes and the original manuscript as submitted to her editor at Vogue, Audrey Withers. We also included the revised manuscript (as printed) and interviews with war survivors, one of whom was actually a French soldier in one of Miller's photos. In writing about her work from this time, McLoughlin describes how Miller's writings, "provide pointers missing from her photographs" (McLoughlin 2010). In our project, we presented the user with a range of visual, textual and interactive objects which, together, create a series of possibilities for exploring and constructing readings of Miller's work and life.

\section{On rephotography}

Rephotography is a practice that offers novel opportunities for engagement with archival materials for both the creator and the viewer. It is sometimes called "repeat 
photography" in the fields of geology and anthropology or referred to as "then and now images" in contemporary press. The rephotographic method has become a tool used to study change in communities, landscapes and built environments.

In this chapter, both the creation and reception of rephotography are of interest. Rephotographic images, when discussed, are often described in terms of how a viewer responds to the images presented. Much has been said about how one might interpret rephotographic material and the possibilities afforded by interacting with work that simultaneously contains both a notional past and a present. While that simultaneous present and the various readings afforded are touched on in this chapter, it is the rephotographic act - that of making a rephotographic image - that bears more consideration.

\section{The act of making a rephotograph}

Rephotographic practice is, in many ways, doubly hands on. It is, at the point of creation, an act of physically reenacting the moment of taking a picture belonging to someone else and of conjoining the two in a single final form. The rephotographer is responsible for undertaking research to determine the precise location and framing of the original in order to create the new image and layering the two. This merging of images can lead to the creation of work which evokes strong reactions. It is described by Kalin in his work on memory and rephotography as, "a style of engagement with the past, a visual style and aesthetic, that reorients the time and place of memory" (Kalin 2013, 172).

In an interview about the act of rephotography Mark Klett, founder of the Rephotographic Survey Project (RSP), describes the act of creating rephotographic images as one which "increased our ability to visualize space and time relationships”. (Rothman and Klett 2011). Klett's project included restaging images originally shot by land surveyors in late nineteenth century North America, more than one hundred years after they were originally made. Having trained as a geologist, Klett's work began largely with landscape images but has expanded in recent decades to include urban environments and other subjects. Cultural historian Rebecca Solnit accompanied Klett during the process of making rephotographs of work by Eadweard Muybridge and others in Yosemite. She describes the feelings she experienced as a result of taking part in those acts of creation by saying that

afterward each place had imprinted on me - it wasn't that I could recall the place with some sort of photographic accuracy, but that it had become part of me, that when I thought of it there was a definite feeling, not an image of place but a sense of place.

(Solnit 2004)

Solnit's articulation of feeling a sense of place is eerily similar to the ways that members of my own team described their experience of rephotographing Lee Miller's work in St Malo. That articulation of the sense of a place as somehow 
larger than the image that was taken there suggests that the creators of the rephotographic image were having the same kind of experience as the viewers. Both seem to be engaging in some kind of temporal drift where the real and imagined places exist simultaneously. Later in this chapter, I will return to exploring the act of rephotographing Lee Miller's work in St Malo and this notion of place. That project employed interactive rephotography. There are, however, many ways of presenting rephotographic material. The primary forms of rephotographic practice one might encounter are touched upon below.

\section{Types of rephotography}

Standard formats for presenting rephotographic work have emerged over the past few decades. They range from the wholly static side-by-side images to fully interactive overlays, with a range of styles in between. The most common of these formats and their differing qualities are described below.

\section{Side-by-side}

Side-by-side presentation is a comparative style of repeat photography in which the original image and contemporary image are, as described, placed side by side. While both images are visible, viewers can only focus on one at a time when looking at an image in any great detail. This format is the one commonly employed in geographic studies and has been used for decades as a tool to measure change within landscapes. This is perhaps the most common format for presenting rephotography.

\section{Embedded}

An increasingly popular method for presenting rephotographic material is that of holding an historic image up in front of a contemporary place so that both can be photographed together. This can be seen commonly in the "Looking Into the Past" Flickr group. This style, like the split style, shows past and present within the same frame. A crucial difference is that the older image actually hides or masks part of the newer. While this style is aesthetically pleasing, it is also problematic in the way that the past effectively obliterates the present.

\section{Split}

Another common form for the presentation of rephotographic images is the split image showing past and present on either side of a vertical axis within the same frame. These can be presented as static or interactive images with the most common being to present the image with a static split. Some forms of split rephotography contain degrees of photo manipulation and interactivity described below.

A variation on the split image is the selective inclusion of elements of the past where, for example, people or other elements may be placed in the present, 
rendered in black and white but without significant borders or other lines around them. It is implied that the photo-manipulation in these images is used only to draw and soften the boundaries between the two but that the contents of both original and newer image remain intact. ${ }^{1}$

\section{Interactive split}

An increasingly popular format for presenting rephotography is the interactive split model. In this, a vertical line in the image can be dragged to the left and right, changing the point at which the old image and new image meet. The National Park Service has produced the Klondike Gold Rush project in which this method is used to present rephotographic images. Though interactive split images allow increasingly active engagement on the part of the viewer, they still struggle from the problem that only part of each image is visible at any one time.

\section{Interactive overlay}

The most interactive format for presenting rephotography sees the images overlaid and includes an interface for users to fade back and forth between the two, either by scrolling left and right or through some other means of interactivity such as the use of a touchscreen or other interface. The interactive overlay allows viewers to see both the original and the rephotographic images simultaneously fading into and emerging from another. It is this format that we employed in Traces of Lee Miller and it can also be seen in David Levene's project The American Civil War Then and Now (Levene 2015). This interactive overlay allows a viewer to actively interact, giving her the freedom to reconfigure material within a frame exploring new forms of both content and meaning-making. This format gives the viewer an opportunity to engage with the relationship between space and time in much the same way as

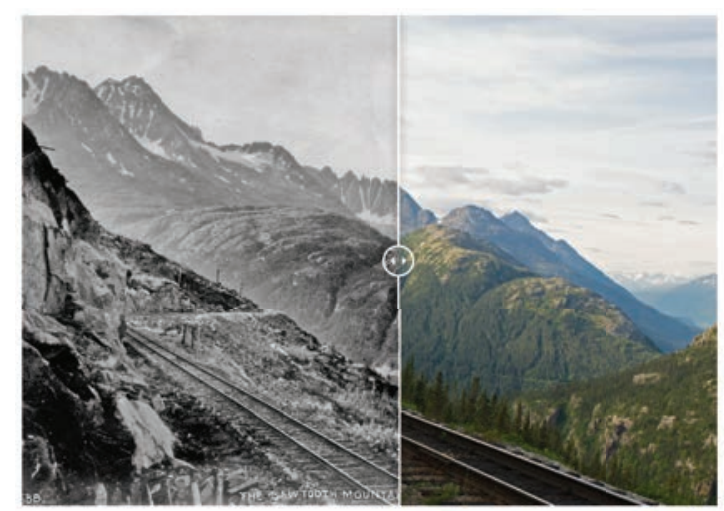

FIGURE 5.2 This image is interactive on the National Parks Service Klondike Gold Rush Site (https://www.nps.gov/klgo/learn/nature/repeatphotography.htm). 
Klett described when discussing the act of actually creating rephotographs. It is this form of rephotography that often leads viewers to describe the presence of ghosts or to talk of a kind of daydreaming or temporal drift taking place as they interact with the images. It is these type of interactive rephotographic images that I wish to discuss in the most detail.

\section{Tracing footsteps}

This chapter builds upon my previous work, including Traces of Lee Miller: Echoes from St Malo, a rephotographic project that focused on Miller's photos of and experience in St Malo during the Second World War. While not my only rephotographic project it was the most expansive and it saw the largest number of people interacting with it around the world. It was produced as a DVD available for purchase and was also shown around the world including alongside an exhibition of Miller's work at the Victoria and Albert Museum in London, as part of a touring exhibition in New Zealand and Australia, and as part of an exhibition entitled Curating Knowledge in England.

Creating rephotographic images requires careful planning and close study of the original materials. Rephotographers must analyse images for the visual cues provided by buildings and other environmental elements. Architectural details and pronounced features of the landscape in an original can be used to help determine the point from which to take the rephotographic image. In studying Miller's material from St Malo, change (and specifically, the destruction and later reconstruction of the city after the War) presented serious challenges. In developing our project, we devised an interface that included access to Miller's original images alongside a range of relevant materials. These included her contact sheets which provided context and her own commentary on the images. Other items of hers including maps and her own handwritten notes were also available to users. The project was navigable via multiple pathways each with its own interface. One was a simple timeline allowing people to explore the rephotographs and related materials chronologically. The other was a map showing the location of each image set. The final pathway was presented as a series of themes that emerged from studying the material as a whole. They included topics such as everyday life in war, the experiences of soldiers, the act of being a journalist and the challenges of actual physical movement. Users could explore the rephotographs along thematic lines.

Each element of the project's interface was driven by what we learned in the process of rephotographing Miller's work. The act of creating the rephotographs forced us to study Miller's images and associated writings closely and to follow in her footsteps as we recreated them. While we expected the process to reveal details about how the world, and specifically the built environment, changed, we were surprised at the other things we learned about the spaces we inhabited. We learned that the framing of the original image, when recreated at the location in which she stood to take it, told us rather a lot about the original photographer. As we retraced Miller's steps through St Malo, pointing our cameras where she once pointed hers, 
we began to see her stance change. As she experienced the war in St Malo, Miller seemed to hold her camera differently. Through physical positioning a kind of embodied knowledge began to emerge from the rephotographic act.

What we learned about the act of rephotography through the process of staking out and re-shooting each of the images from Miller's time in St Malo was that the movements of the photographer and the framing of the images themselves told a story. Having arrived in St Malo amid active combat, Miller's photographic process was affected by the space around her. As she spent more time in the war-torn town, her images were shot from increasingly lower points of view, suggesting that perhaps she was shooting from a tenser or less visible space. The focal points within the images varied, and contact sheets revealed that the images were shot rapidly and often in a way that suggested a photographer on the move. The images Miller chose to shoot in the spaces between locations, perhaps en route from one to another, suggest her path through the city and the encounters she might have had. These paths, as retraced when creating the rephotographs, show surprising patterns of movement which, when considered alongside her own notes from the period, highlighted Miller's concerns. She often commented on how the details of everyday life became complicated and regularly used her camera to capture them. The life of the GI himself and the notional everyday nature of his existence emerged as an analogous but different concern. She followed people, looking not for large moments of conflict but for the moments of pause, of rest: lingering in an archway to look at the light; resting on the stoop outside of a building; sitting quietly at a desk lost in thought.

Traces of Lee Miller utilizes rephotography to highlight the impermanence of the world we inhabit. A viewer's presence causes the images to merge and fade. By being there, viewers cause the images to retreat into one another. Their very presence interacting with the work creates instability within the frame of the image. The project itself includes a large number of interactive rephotographs of Miller's work as well as hundreds of images of her own notes, contact sheets and other ephemera from that time. When creating the project, we chose to build it around rephotography as the form offered both artists and viewers the opportunity to come to new understandings about that period in Miller's life through the reframing and recontextualization rephotography allows. The project allowed users direct engagement with Miller's work whilst navigating existing and new narratives emerging from it.

\section{Participation and exchange: the rephotographic impulse}

There has been much debate about how the digital age is reshaping photography. While it may be simpler to accept more pessimistic views regarding changes in both the material form and reception of photography, digital media also brings with it a distinct potential for expanding photographic practices. The act of creating rephotography could be seen as an example of a kind of expanded photographic practice which, through its very form encompasses acts of both participation and exchange. 
In his introduction to The Art of Participation exhibition at the San Francisco Museum of Modern Art, Rudolf Frieling highlights the importance of systems of exchange between artist and viewer. While these are relationships we rehearse in various ways across media, his comments bear consideration. Frieling asks whether "new modes of communicating and distributing information change a museum's policies and attitudes" (Frieling 2008). While we are not exploring curatorial practice, his comments remain relevant precisely because he highlights the nature of certain exchanges between creators and audiences that can be seen across rephotographic practice. Frieling suggests that "the process of mutual exchange between visitors, users, artists, curators, and collectors is essential" (Frieling 2008).

It is that process of mutual exchange that we see in the rephotographic image not least because these images are built on an assumption that viewers are encouraged to interact with them literally or imaginatively, leading to a consideration of the effects of change. In rephotographic practice the original photographer, rephotographer, viewer and other members of the team involved in the project engage in a kind of mutual exchange as they engage with the creation and viewing of images that hold multiple simultaneous moments of the present. That strategy of considering the exchange informed the process of creating Traces of Lee Miller.

The roles of the rephotographer and the viewer are separate, and, for each, distinct discoveries can be made. In the case of the rephotographer, the act of retracing the footsteps of the original photographer and of recreating the framing can lead to an understanding of, among other things, the space she occupied. For the viewer encountering a rephotograph, there is much to be learned about what has changed between the two images both in terms of what has gone but also in terms of what is new. In images where people or buildings are present, the viewer may find herself wanting to know more about who or what has disappeared or emerged within the images. The rephotographer chases the ghost of the photographer while the viewer chases those who may or may not have come before.

While rephotography has its roots in the landscape images of geological study, the choice of image and the distance in time between the original and its rephotograph can reveal a range of different types of knowledge. In urban spaces or war-torn regions where much has occurred, details emerge that speak largely to absence, change and decay. In geological contexts, when rephotographing landscapes that change more slowly over time, the information revealed within the image may show small changes which relate to more significant events. In both instances, the possibility of knowledge discovery exists for both the photographer and the viewer as each is forced to contend with the changing spaces in which the image is taken and with the actual change which emerges within the frame between the two images. In his writings about rephotography as encountered by viewers, Kalin proposes a kind of ghostly ontology or hauntology inside of which the multiple times and places represented in the images coexist and are complicated by our own present readings of them. He suggests a kind of becoming or an emergent state in the work: "Rephotography as hauntography produces a different style 
of engagement with memory that disrupts the linear flow of time by circulating and accumulating many times and places" (Kalin 2013, 177).

These multiple possible readings of rephotographs that engage with memory and can be disruptive present interesting challenges when considering the indexicality of the image. Doane (2007) directly addresses the tendency, in a digital era, to highlight the problematic state with photography. She explores how the wholly digital image, lacking in its chemical processes, is difficult to locate in a specific time or place in the same way as a more traditionally produced photograph could be seen to have come into being in the moment it was taken, therefore linking it to the moment of its creation. Through her work, however, she arrives at a suggestion that in many ways describes the state of rephotography. It effectively privileges the materiality of the photochemically produced image over the ephemerality of the digital image. She suggests that the former offers a promise that, "is that of touching the real" (Doane 2007). In rephotography, however, the act of constructing a rephotograph itself creates an interaction between the notional real and the digital which could be seen in some ways as touching the real.

When deriving meaning from context we are activating a kind of indexicality. Consequently, it becomes useful to consider the rephotographic act as an indexical statement. Rephotography is unique in its insistence that the audience simultaneously read multiple images as one. It could be described as polysemic in the way that rephotographs encourage close readings which invite viewers to engage in multiple simultaneous readings. In her work on rephotography and witness, Miles describes how the past and present converge, describing how "rephotographs challenge historical distanciation" because "the 'then' of past and the 'now' of the present become entangled with one another" (Miles 2016, 65).

\section{Encounters and disappearances}

I regularly create opportunities for viewers of my work to share their experiences. As my work has toured the world, people have regularly reported feeling as if they'd seen ghosts, or that interacting with the rephotographs had caused them to "daydream" or "think about what was missing". Rephotographic practice creates the conditions for that kind of temporal drift that often leads users to express feelings of nostalgia. They repeatedly asked questions about what happened to the children playing on the tanks in the middle of a road within a picture from the Second World War. They wondered why once-bustling streets now seemed empty. In an image taken within a hotel that served as a command point, they often spent significant time watching the soldiers appear and disappear within the images.

In observing people interacting with the images, we would regularly see them slowly explore what has changed in each. The amount of time spent on each image was longer than we anticipated in nearly every instance. After interacting with the rephotographs, people seemed eager to talk about their experience and to wonder aloud about disappearances. They often commented on the changes they have seen in their own lives and world in the time roughly represented by the images. 


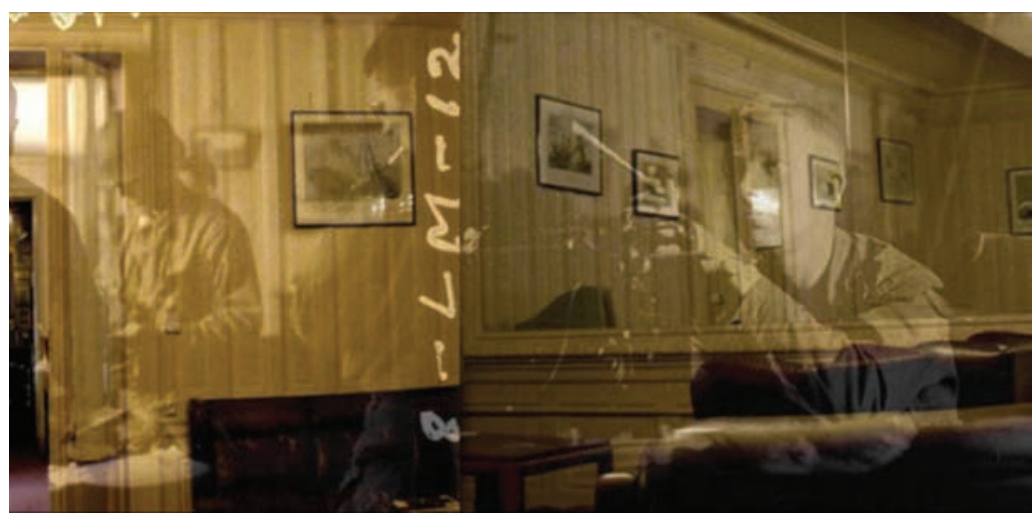

FIGURE 5.3 An image from the project Traces of Lee Miller: Echoes from St. Malo.

In the same way that Miles describes an entangled then and now in her writing about rephotography, viewers seem to articulate a space where then, now and the personal become entangled. As Solnit described the way that the place of the rephotographic act imprinted on her, one could argue that the moment of actively interacting with rephotographs had a similar effect on viewers.

In the early twenty-first century, rephotography has become increasingly popular. Once a tool used largely by geologists, photographers and artists, the practice of creating repeat photographs has become more widespread. Through a combination of the rise of web-based sites where people share their images and institutions including newspapers and museums producing rephotographic projects, they have become more visible in a number of areas. Writing about the work of Argentinian photographer, Gustavo Germono, Miles suggests that this trend represents acts of reconciliation. "Rephotography has become a particularly popular trend in recent years, as amateurs and professional alike seek to represent change in their personal lives and environments, and reconcile an aspect of the past and with the present" (Miles 2016, 54). In the Appendix to this chapter, a number of rephotographic projects are described. They represent a range of work spanning the personal, the geographical and the historical. The projects employ a range of practices discussed here and offer the potential for further engagement.

\section{Conclusion}

Rephotography provides unique opportunities for discovery to both photographers and audiences. The simultaneous reading of multiple images necessitated by rephotography creates the condition for audience members to construct meaning from a range of possibilities. Current writing about rephotography has tended to focus upon the experiences of viewers as they engage with the images, highlighting the ways in which they interpret the work. Few, however, have explored what can be learned from the act of creating rephotographs. 
Rephotographic practices are by their very nature 'hands on'. In making them we combine the 'then' of the original image with the 'now' of the rephotograph to create new work. By using rephotographic practices, we might gain new insights into the images, their creators and the spaces in which they were taken. As we discovered when creating Traces of Lee Miller: Echoes from St Malo, the embodied practice of retracing the steps of the original photographer and of recreating the framing of the original image lead to new insights about the work and its wider context. When shared with audiences, those insights could open even more possibilities when interacting with the work. In creating and interacting with rephotographs, we occupy a space between the moments of the original image and its rephotograph. In it we find disappearances, appearances and change. In that space the distance between then and now is different, and in that difference I believe there are still discoveries to be made.

\section{Appendix}

\section{The American Civil War Then and Now}

David Levene's project rephotographing American Civil War sites in 2015.

https://www.theguardian.com/artanddesign/ng-interactive/2015/jun/22/ american-civil-war-photography-interactive

\section{The Desert Laboratory Repeat Photography Project}

Perhaps the largest collection of its kind in the world, these images are created to help researchers understand the effects of changes in climate and land use in deserts across the world.

https://pubs.usgs.gov/fs/2007/3046/fs2007-3046.pdf

\section{Exploring Land Cover Change Through Repeat Photography}

A project cosponsored by the University of Alaska and the National Parks Service, it is similar to other repeat photography projects and it also encourages citizen scientists to get involved in documenting landscape changes in the Denali National Park and Preserve.

http://denalirepeatphotos.uaf.edu/

\section{Klondike Gold Rush: Capturing a Century of Natural Resource Change Through Repeat Photography}

In this project, repeat photography is used to show change in a national park. The interesting or novel thing about this is that is used the more contemporary central slider allowing people to position the point of distinction between the two images at any point across the image. They can slide the differentiating line 
between past and present back and forth. These can be seen in the National Parks Service Klondike website.

https://www.nps.gov/klgo/learn/nature/repeatphotography.htm

\section{The Repeat Photography Project}

A United States Geological Service project that uses rephotography to showcase forestry-related sequences of images.

http://www.repeatphotography.org/intro/

\section{Thomas P. Peschak}

Peschak, a National Geographic photographer, uses rephotographic practices to highlight environmental change.

https://www.worldpressphoto.org/collection/photo/2018/environment/ thomas-p-peschak

\section{Vincent Zénon Rigaud}

Rigaud has produced a wide range of rephotographic images showing past and present, often with a central blurred line between the two.

http://vincentzenon.com/rephotography-repeat-photography

\section{Note}

1 For an example of the selective static split technique, see Danielle Cadet's Huffington Post article about 'then and now' images of significant moments in American history (Cadet, 2014).

\section{Bibliography}

Anon (n.d.) Capturing a Century of Natural Resource Change Through Repeat Photography [online]. Available from: https://www.nps.gov/klgo/learn/nature/repeatphotography. htm (Accessed 11 November 2017)

Anon (n.d.) Looking Into the Past [online]. Available from: https://www.flickr.com/groups/ lookingintothepast/ (Accessed 12 December 2017).

Cadet, D. (2014) Then And Now Photos Recall The History In Places We See Every Day [online]. Available from: https://www.huffingtonpost.com/2014/02/21/then-and-now-photosblack-history-month_n_4826565.html (Accessed 4 December 2018)

Doane, M. A. (2007) The Indexical and the Concept of Medium Specificity. Differences, 81(1): 128-152.

Engelmann, T. (2007) Who Are Our Fathers? Journal of American History, 94(1): 163-171.

Frieling, R. and San Francisco Museum of Modern Art (eds.) (2008) 'Introduction', in The Art of Participation. New York: Thames \& Hudson.

Kalin, J. (2013) Remembering with Rephotography: A Social Practice for the Inventions of Memories. Visual Communication Quarterly, 20(3): 168-179. 


\section{Mary Agnes Krell}

Levene, D. (2015) The American Civil War then and Now [online]. Available from: http:// www.theguardian.com/artanddesign/ng-interactive/2015/jun/22/american-civil-warphotography-interactive (Accessed 8 November 2017)

McLoughlin, K. (2010) Glamour Goes to War: Lee Miller's Writings for British Vogue, 1939-45. Journal of War and Culture Studies, 3(3): 335-247.

Miles, M. (2016) Rephotography and the Era of Witness. Photographies, 9(1): 51-69.

Rothman, A. and Klett, M. (2011) Views Across Time. Places Journal. [Online] Available from: https://placesjournal.org/article/views-across-time/ (Accessed 4 November 2017)

Solnit, R. (2004) Slow Seeing: How a 'Rephotography' Project Taught Me to Go Beyond Looking. The Utne Reader. (May/June).

Winter, J. (2001) The Generation of Memory: Reflections on the "Memory Boom" in Contemporary Historical Studies. Canadian Military History, 10(3): 57-66. 